\title{
Coasian and Modern Property Rights Economics
} A Case of Kuhnian Lost Content

\author{
Foss, Kirsten; Foss, Nicolai J.
}

Document Version

Final published version

Publication date:

2014

\section{License \\ CC BY-NC-ND}

Citation for published version (APA):

Foss, K., \& Foss, N. J. (2014). Coasian and Modern Property Rights Economics: A Case of Kuhnian Lost Content. Institut for Strategic Management and Globalization. SMG Working Paper No. 1/2014

Link to publication in CBS Research Portal

\section{General rights}

Copyright and moral rights for the publications made accessible in the public portal are retained by the authors and/or other copyright owners and it is a condition of accessing publications that users recognise and abide by the legal requirements associated with these rights.

Take down policy

If you believe that this document breaches copyright please contact us (research.lib@cbs.dk) providing details, and we will remove access to the work immediately and investigate your claim. 
COASIAN AND MODERN PROPERTY RIGHTS ECONOMICS:

A CASE OF KUHNIAN LOST CONTENT

\author{
Kirsten Foss
}

And

Nicolai Foss

SMG WP 01/2014

January 25, 2014 
SMG Working Paper No. 01/2014

January, 2014

ISBN: 978-87-91815-94-2

Department of Strategic Management and Globalization Copenhagen Business School

Kilen, Kilevej 14A

2000 Frederiksberg

Denmark

www.cbs.dk/smg 


\title{
COASIAN AND MODERN PROPERTY RIGHTS ECONOMICS: A CASE OF KUHNIAN LOST CONTENT
}

\author{
Kirsten Foss \\ Department of Strategy and Leadership \\ Norwegian School of Economics \\ Helleveien 30; 5045 Bergen \\ Norway \\ Kirsten.Foss@nhh.no \\ Nicolai Foss \\ Department of Strategic Management and Globalization \\ Copenhagen Business School; Kilevej 14, $2^{\text {nd }}$ floor \\ 2000 Frederiksberg; Denmark \\ Njf.smg@cbs.dk \\ January 25, 2014
}

\begin{abstract}
Among the many seminal contributions of Ronald Coase, founding property rights economics is a truly major one. This approach impacted a number if fields in economics in particularly the 1960s and 1970s, but gradually lost influence. What is called property rights economics in modern economics, mainly originated by Oliver Hart, is very different from the original property rights economics of Coase, Demsetz, Alchian, Cheung, Umbeck, Barzel, etc. in terms of analytical style and explanatory scope. Based on our earlier work on the subject (Foss and Foss, 2001), we argue that the change from Mark I to Mark II property rights economics led to Kuhnian loss of content. This is related to the strong assumptions concerning the definition and enforcement of ownership rights made in the latter approach which leads to many real life institutions and governance arrangements being excluded from consideration.
\end{abstract}

JEL Classification: D23, D80, L22

Key words: Ronald Coase, ownership, property rights, institutional analysis. 


\section{INTRODUCTION}

The Nobel Prize was conferred upon Ronald Coase in 1991 "for his discovery and clarification of the significance of transaction costs and property rights for the institutional structure and functioning of the economy." Notions of property rights and their economic implications had surely made an occasional appearance in economics prior to Ronald Coase's 1960 paper, “The Problem of Social Costs.” Early examples are Commons' (1924) magisterial work, Knight's (1924) critique of Pigou’s analysis of how taxation may address road congestion; Mises' (1936) critique of how socialist economists neglected systematically neglected incentive problems that accompany the property rights arrangements of socialist economies; or Alchian's (1958) analysis of the economics of universities. However, it was not until Coase's 1960 paper (anticipated, of course, by Coase, 1959) that it became clear that the property right constitutes a distinct and important unit of analysis in economics, a unit that can be dimensionalized in a number of ways, thereby providing insights into economic behaviors and their consequences that escape analysis that suppress property rights by making idealized assumptions about them (e.g., that they can be costlessly enforced).

Coase's seminal analysis of how conflicting resource claims can be resolved by well-defined property rights when transaction costs are low and wealth effects are absent prompted a literature on property rights economics that spanned economic history (Alchian \& Demsetz, 1973; North, 1990), industrial organization (e.g., Alchian \& Demsetz, 1972; Alessi, 1983), contract economics (Cheung, 1969, 1970), resource and agricultural economics (Libecap, 1989; Anderson \& Hill, 1990; Allen \& Lueck, 1998; Schlager \& Ostrom, 1992, law and economics (e.g., Calabresi \& Melamed, 1972; Lueck, 1995), and comparative systems (Furubotn \& Pejovich, 1972).

Much of this work was focused on identifying differences in outcomes (i.e., allocative efficiency) across between alternative systems of property rights understood as alternative ownership arrangements, examining in the process the emergence and transformation of property rights

\footnotetext{
${ }^{1}$ http://www.nobelprize.org/nobel_prizes/economic-sciences/laureates/1991/coase-facts.html 
(Demsetz, 1967), the connectedness of property rights in systems (Alchian, 1965), and their connections to law, norms and customs (Demsetz, 1964). Towards the end of the 1960s, outside observer would be justified in thinking of the "economics of property rights" as a clearly successful approach. Thus, in a 1972 review article Furubotn and Pejovich (1972: 1156) declared that “... property rights analysis does offer a fresh and useful way of looking at economic problems. Substantial advances have already been achieved and the literature gives evidence of continuing vitality and promise of future accomplishment."

In hindsight, were Furubotn and Pejovich right—in particular has the approach exhibited “continuing vitality" and "accomplishment"? On the one hand, prominent economists, like Armen Alchian, Yoram Barzel, (Coase-student) Stephen Cheung, Harold Demsetz, Eirik Furubotn, and John Umbeck, were directly associated with property rights economics. Nobel Prize-winning economists Douglass North and Ellinor Ostrom have both used property rights economics in their work.

On the other hand, however, few economists today define themselves as working in the tradition of the property rights economics of the $1960 \mathrm{~s},{ }^{2}$ what we here call "Mark I property rights economics." This is not to say that property rights are unimportant in contemporary economics. In fact, the arguably dominant contemporary approach to the economics of the firm is often called "property rights theory" (Grossman \& Hart, 1986; Hart \& Moore, 1990; Segal \& Whinston, 2012), what we call “Mark II property rights economics.” However, contributors to the Mark II research stream provide at best sparse reference the older property rights literature. For example, a recent authoritative chapter on "property rights" (Segal \& Whinston, 2012) and published in the prestigious Handbook of Organizational Economics (Gibbons \& Roberts, 2012) only mentions Coase (1960) and Demsetz (1967) in passing, and then concentrate all the attention on the modern, Hartian, Mark II approach. Property rights economics like Alchian and Demsetz are cited for their contributions to

\footnotetext{
${ }^{2}$ Examples of currently active Mark I scholars include Douglas Allen, Lee Alston, Thrainn Eggertson, Gary Libecap,and Dean Lueck.
} 
the economics of the firm (Alchian \& Demsetz, 1972; Klein, Crawford \& Alchian, 1978) rather than for their contributions to "pure" property rights economics.

The lack of attention to the older property rights work may seem puzzling. The puzzle vanishes, however, when it is realized that the economics of property rights Mark I was only one among many other advances in a decade, namely, the 1960s, that was extraordinarily rich in new theoretical innovation in economics. Thus, the decade witnessed fundamental breakthroughs in the economics of uncertainty and information, human capital theory, the first stabs at what would later be called "agency theory" and "mechanism design," and other advances in mathematical, formal economics, many of which were cast within the general equilibrium theory that dominated pure theory. Mark II property rights theory is directly placed within this tradition, as moderated by the game theoretical revolution of the 1980s. In contrast, Mark I property rights theorists largely worked in a non-mathematical mode, and this may account for the fact that they are seldom cited in modern research on property rights of the Mark II variety.

More is at stake here than duly citing those who contributed the founding, seminal insights. To be sure, much of the early analysis has been absorbed in the economic mainstream (e.g., the basic idea that externality problems are problems of ill-defined and/or costly-to-trade property rights). But not all has, and modern property rights economics is considerably more narrow than the approach pioneered by Coase. In fact, we argue in this paper that there has been something to the Kuhnian "loss of content" (Kuhn, 1996) of paradigmatic change in the move from Mark I to Mark II property rights economics. Thus, property rights economics Mark II represents a substantially more narrow approach in terms of the phenomena it investigates, namely why it matters who owns the asset(s) in a relation that spans at least two stage of production in a value chain. The analysis is typically, if not exclusively, cast in the context of vertical firm boundaries (Grossman \& Hart, 1986; Hart \& Moore, 1990) and internal organization (e.g., Rajan \& Zingales, 1998). Moreover, it deals predominantly with ownership rather than with the analytically different category of property rights. Ownership is 
seen as conferred by holding legal title to an asset, and gives owner "residual rights of control," that is, rights to make decision in un-contracted for situations. Ownership is seen as unambiguous and is assumed to be indivisible, perfectly defined and enforced. This is a specific manifestation of Hodgson's (2004) broader argument that the "notion of the firm in economics ... has become dangerously devalued of legal meaning and much institutional substance" (Hodgson, 2004: 37).

In contrast, in Mark I property rights theory, ownership was never pinned down with much precision, and interpretations of what exactly ownership entails fluctuated somewhat over the course of development of the older approach. Most understandings highlighted exclusivity and alienability of property rights as central to the definition of ownership. This makes effective ownership dependent on private and legal enforcement of claims to ownership, establishing a broader link to institutions (Sened, 1997). Mark I property rights economics also stressed how assets have multiple attributes to which rights may be held by many different individuals (Alchian, 1965; Barzel, 1997). Some of these rights may be contested and captured. Individuals may rationally decide not to protect certain rights. This all makes ownership an ambiguous and fleeting phenomenon, depending on the social institutions, private enforcement and public policy existing at any given point of time. This was, however, never seen as a problem by Mark I property rights economists. On the contrary, the complex and contingent nature of real ownership arrangements points to the many margins on which individual can exercise capture of rights, how they seek to protect their rights, the resources consumed in this process, and the role of institutions in facilitating and constraining such processes (cf. Alessi, 1990). This institutional research program, outlined in its essence by Coase (1960), is considerably richer than the one implied by Mark II property rights economics.

\section{COASE AND PROPERTY RIGHTS ECONOMICS}

\section{Property Rights Economics Mark I}

Mark I property rights theorists often portray the economics of property rights as a set of extensions of basic price theory, or applied neoclassical economics (e.g., Furubotn \& Pejovich, 1972; 
Eggertson, 1990). Specifically, property rights economics Mark I is characterized by insisting that (1) the utility-maximisation hypothesis be applied to literally all choices (Alchian, 1958, 1965; Barzel, 1997); (2) all of the constraints implied by the prevailing structure of property rights and transaction costs be considered (e.g., Demsetz, 1964; and (3) the contractual, organisational, and institutional implications of (1) and (2) must be identified and explained (Alessi, 1990). To put it in a compact manner, property rights economics is about the explanatory consequences of an expanded and refined understanding of individuals' opportunity sets relative to standard price theory (Umbeck, 1981). Property rights may be seen as the explanatory vehicle that is deployed to unfold this view (Barzel, 1997).

The older property rights literature arguably typically defines property rights as the rights to exercise choices over productive resources and to keep the income derived from their use (Alchian, 1965). ${ }^{3}$ In other words, at the heart of the (economic) notion of property right is effective control (barzel, 1997). Transaction costs, in this conception, are not simply the "frictions" associated with trading — finding trading partners, writing contracts, hiring lawyers_-, but are more generally the resources spent on delineating, protecting, and capturing de facto property rights (Eggertson, 1990; Barzel, 1994, 1997), whether they are being traded or not. ${ }^{4}$

\section{Coase as the Founder of Property Rights Economics}

While the above is a characterization that is informed by the hindsight provided by more than fifty years of theoretical development, in actuality property rights economics developed somewhat differently. Thus, the decisive event is the introduction of a new unit of analysis in a specific context, namely the analysis of externalities in Coase (1960), and the three characteristics above unfolded

\footnotetext{
${ }^{3}$ Legal scholars may distinguish between "property" (i.e., having usus, fructus, and abusus rights) and "possession" (i.e., having only usus and abusus rights). However, the early property rights economists theorists did not make this distinction.

${ }^{4}$ Allen (1991) usefully distinguishes between a narrow, trade-based notion of transaction costs, which he calls the "neoclassical approach," and a broader, property-rights view. In the neoclassical view, transaction costs are analogous to search costs or transportation costs, and can be analyzed as any other cost of doing business.
} 
only gradually over the following decade. Thus, the full implications of the zero-transaction-costs assumption — for example, that monopolies do not influence resource allocation (Demsetz, 1964), all institutional alternatives are efficient (Cheung, 1969), market structure is indeterminate (Furubotn, 2002), etc. - emerged as a result of critical reflection on the analytical benchmark in Coase (1960). While that benchmark has famously attracted massive attention, Coase himself toned down the importance of the "Coase theorem" in favour of the importance of the legal, contractual, and institutional ramifications of transaction costs (Coase, 1988b). However, underlying the various innovations in Coase (1960) is an equally important innovation: The introduction of a new unit of analysis, namely the property right, and the "corollary" notion of exchange as involving the more or less costly exchange of more or less well-defined property rights

The specific context of the introduction of this new unit is a discussion of the economic implications of allocating legally delineated rights (liability rights) to a subset of the total uses of an asset, namely those that have external effects on the value of other agents' abilities to exercise their use rights over assets. As part of his critique of the Pigovian tradition in welfare economics, Coase (1960: 155) notes that a reason for its failure to come fully to grips with externality issues lies in its "faulty concept of a factor of production." According to Coase (1960: 144), it is often more productive to think of a production factor, not as a physical entity but as a right to perform certain actions: "We may speak of a person owing land and using it as a factor of production but what the land-owner in fact possesses is the right to carry out a circumscribed list of actions." He immediately moves on to noting how such property rights are inherently constrained:

The rights of a land-owner are not unlimited. It is not even always possible for him to remove the land to another place. For instance, by carrying it. And although it may be possible for him to exclude some people from using "his" land, this may not be true of others. For example, some people may have the right to cross the land. Furthermore, it may or may not be possible to erect certain types of buildings or to grow certain crops 
or to use particular drainage systems on the land. This does not come about simply because of Government regulation. It would be equally true under the common law. In fact it would be true under any system of law. A system in which the rights of individuals were unlimited would be one in which there were no rights to acquire.

Since property rights are not "unlimited" in this sense, mechanisms for handling their allocation arise. A fundamental insight emerging from Coase's work is that transactions involve the exchange of property rights (rather than goods and services per se). Moreover, property rights to an asset can be partitioned in various ways and, hence, different individuals may hold (different) property rights to the same asset. ${ }^{5}$ Given this, ownership is defined as the possession of "the right to carry out a circumscribed list of actions" (1960: 144), that is, ownership of an asset is a bundle of rights to use that asset. The vector of rights is circumscribed partly by legal or governmental restrictions, and, as stressed in the works of particularly Umbeck (1981) and Barzel (1997), partly by the ability of the holder to exclude other agents from the specific uses defined by the rights. Thus, in a Coasian view ownership does not provide the owner with exclusive rights to assets, only to certain uses of the asset.

Perhaps for this reason ownership per se is not what primarily interests Coase in the 1960 paper. Indeed, a reading of that paper leaves one with the impression that ownership is something of an epiphenomenon, at best derived from the more fundamental notion of use rights (so that holding a certain minimum bundle of non-trivial use rights make one the effective owner). Indeed, Coase's major concern is the allocation of use rights to assets. In the zero transaction cost setting underlying the Coase Theorem, all possible uses (including future ones) of assets are known and can be contracted for (Furubotn, 1991; Barzel, 1997). All rights to "carry out a circumscribed list of actions" will be costlessly delineated and costlessly contracted for. Mark I property rights theory suggests it is

\footnotetext{
${ }^{5}$ Much subsequent work within property rights economics has refined this insight, applying it to issues like public ownership and the public corporation. Barzel's (1997) work in particular has been taken up with examining the behavioral and allocative consequences of the multi-attribute nature of most assets.
} 
possible to examine the consequences for allocative efficiency of a contractual allocation of use rights without involving the notion of ownership at all, as in complete contracting theories (e.g., agency theory) (Hart, 1995). This is, of course, correct. However, it is more questionable to then infer that there can be no room for the ownership construct in such a world (i.e., that transaction costs have to be present for ownership to be meaningful). For example, wouldn't holding all property rights rights to a given asset qualify one as "the owner," regardless of what is assumed about transaction costs? In any case, such discussions do not explicitly surface in Coase (1960).

\section{Later Developments}

The understanding of the nature of property rights evolved within Mark I property rights economics. Coase (1960) was mainly interested in the efficient allocation of use rights to assets. Demsetz (1964) and Alchian (1965) went beyond this, defining property rights as individuals' rights to use, derive income from, and alineating assets, a definition corresponding to the partition in Roman law between usus, fructus, and abusus, respectively. The relation to property law was also debated. It became increasingly held that property rights can be analysed conceptually apart from legal considerations (some scholars therefore talk about "economic rights," e.g., Barzel, 1997). In fact, some scholars argued that property rights may exist in the absence of the state, that is, under wholly anarchic conditions (Bush \& Mayer, 1974; Umbeck, 1981). Physical force or strong social norms may guarantee de facto control over the uses of and income from a resource. It also became clear that property rights have an inherently forward-looking dimension. Finally, it became clear that from an economic perspective property rights can be understood in value terms and that agents seek to maximise the value of the control they hold over assets.

In line with such ideas, Alchian and Allen (1969: 158) offered a highly compact definition of property rights as "the expectations a person has that his decision about the uses of certain resources will be effective" (see also Cheung, 1970). This understanding places all of the emphasis on effective 
control and completely deemphasizes any legal connotations of the property rights construct. In a more recent statement, Barzel (1994: 394; emphasis in original) defines property rights as an individual's net valuation, in expected terms, of the ability to directly consume the services of the asset, or to consume it indirectly through exchange. A key word is ability: The definition is concerned not with what people are legally entitled to do but with what they believe they can do.

Property rights in such definitions refer to an individual's expected opportunity set, that is, to the multiple margins on which economizing may take place. Moreover, in contrast to, for example, the stress on property rights as socially sanctioned relations between individuals in Demsetz (1967), property rights in these definitions imply that even Robinson Crusoe will hold property rights. ${ }^{6}$ Thay also suggest that the definition of a property right is independent of legal considerations; to the extent that he holds effective control over an asset, a thief holds property rights to that asset (Barzel, 1997). However, although property rights may thus exist potentially in the absence of law, in reality they have legal counterparts and the value of property rights is influenced by legal sanction and enforcement (Barzel, 1997).

\section{The Ownership Conundrum}

While property rights economics increasingly converged on a compact definition of property rights as effective control, it did not definitively resolve a puzzle that Coase had left unaddressed: What exactly is the economic meaning and function of ownership? Until the emergence of the modern Hartian property rights literature, the literature has typically defined the construct opportunistically, that is, depending on the specific explanatory purpose at hand. For example,

\footnotetext{
${ }^{6}$ In contrast, Demsetz (1967: 347) argues that "[i]n the world of Robinson Crusoe property rights play no role. Property rights are an instrument of society and derive their significance from the fact that they help a man form those expectations which he can reasonably hold in his dealings with others. These expectations find expression in the laws, customs, and mores of a society. An owner of property rights possesses the consent of fellowmen to allow him to act in particular ways. An owner expects the community to prevent others from interfering with his actions, provided that these actions are not prohibited in the specifications of his rights."
} 
Demsetz and Alchian both put much emphasis on the rights to exclude and alienate as the relevant criteria of private ownership in their work on systems of property rights. Owners are those individuals who can exercise these rights (Alchian, 1965; Demsetz, 1967). However, interestingly these authors change their understanding of ownership when they analyze the organization of the firm and corporate governance, where owners get defined as those individuals possessing control rights (Demsetz, 1967) or residual income rights (Alchian \& Demsetz, 1972). The modern finance literature, which to a large extent originates in property rights economics (i.e., Alchian \& Demsetz, 1972; Jensen \& Meckling, 1976; Fama \& Jensen, 1983) has tended to define ownership in terms of residual income rights. More generally, the older property rights literature left unresolved the precise role played by other types of economic rights besides the use rights stressed by Coase (1960), such as rights to exclude, alienate and derive income from assets, in the function of ownership. In fact, Demsetz (1988: 19) argued that the meaning of ownership is inherently "vague" because there is no bound to the number of attributes, uses, etc. of an asset that can be owned, although he thinks that "certain rights of action loom more important than others. Exclusivity and alienability are among them." Thus, one may argue that ownership is fundamentally defined by exclusivity and alienability. For example, Umbeck (1981: 39) identifies ownership with the “... abilities of individuals, or groups of individuals, to forcefully maintain exclusivity." In actuality, such "abilities" depend, of course, on what are recognized as legitimate claims, and therefore involve historically contingent circumstances relating to the positions of power and the ability to exercise force that define and enforce the rights of the owner (Sened, 1997).

\section{Why Ownership Matters}

A possible, and this remains speculative, unifying interpretation of what ownership is about in Mark I property rights economics is that it is shorthand for a list of unspecified use and thus income rights, where excludability can be enforced to different degrees, depending on the particular social 
arrangement and on who holds ownership. Ownership is thus fundamentally contingent, not absolute, because it is dependent on private and legal enforcement. In turn, ownership matters because it determines who can take action to exclude non-owners. Such exclusion is important, because it allows prices to be used as a way of rationing the use of resources and thereby reduce commons-type problems (Barzel, 1997). Ownership also matters because it determines who can alienate (sell, transfer) resources. The obvious importance of this is that alienability reduces the transaction costs of taking advantage of opportunities for wealth creation through exchange (Alchian, 1965). Ownership furthermore matters because it determines who as a default can decide on the use of new types of uses of an asset. This is relevant because it reduce the transaction costs of taking advantage of new uses of assets. Finally, ownership determines how assets are to be used in case of unforeseen contingencies. This matters, because it may act to increase the bargaining power of the owner in a contractual relation. It is this final point that is the centerpiece of the Mark II property rights economics.

\section{FROM COASIAN PROPERTY RIGHTS TO HARTIAN OWNERSHIP}

\section{Property Rights Economics Mark II}

Whereas the emergence of property rights economics Mark I may be dated to the publication of Coase (1960), the emergence of the Mark II stream can be dated to the publication of Grossman and Hart (1986), a paper that has come to define how modern economists conceptualize ownership and address its behavioral and allocative consequences. ${ }^{7}$ The impetus to Coase (1960) was the questioning of how to efficiently allocate use rights to assets like the radio spectrum or cornfields across multiple potential users, implying multiple potential rival uses. Mark II property rights economics emerged in the context of a much more narrow problem: What explains the vertical boundaries of the firm; in particular, what is the role played by asset ownership in explaining observed patterns of firm boundaries? The issue of the boundaries of the firm is of course a staple of 
transaction cost economics, and Mark II property rights economics is sometimes portrayed as a formal version of Williamsonian transaction cost economics (Williamson, 1996). Although this is an incorrect characterization (cf. Kreps, 1996; Williamson, 2000), Mark II property rights economics does borrow one key construct from transaction cost economics, namely incomplete contracts (a construct that is not explicitly present in Mark I property rights economics) (Williamson, 1996). In the context of making sense of ownership, this is seen as a key point by Mark II property rights theorists: When contracts are incomplete, there will be some asset uses that are not regulated by the contract. In this case, there is a need for an institution that allocates use rights to assets in the face of unforeseen contingencies. This institution is private ownership.

Mark II property rights economics begins with the idea that joint ownership of nonhuman, alienable assets is what defines the firm, which means that firm boundaries are delineated by the ownership of such assets. The importance of nonhuman assets derives from their (potential) function as bargaining levers in situations not covered by contract. The allocation of ownership to such levers matter when parties to a relation have to make non-contractible investments in assets that matter to the relation—notably, investments in the parties' own human capital—and these assets are complementary to specific nonhuman assets. The model revolves around the effect of ownership of nonhuman assets on the incentives to invest in human assets. Specifically, bargaining determines the allocation of returns from investments, so that each party gets his opportunity cost plus a share (assumed equal) of the (verifiable) profit stream. Since in this setup individual returns differ from social returns, and agents are sufficiently farsighted to foresee this, investments will be inefficient.

It is possible to influence the investment of one of the parties positively by reallocating ownership rights to nonhuman assets. A reallocation of ownership of physical assets alters the parties' opportunity costs of non-cooperation after specific investments have been made, and thus changes the expected payoffs from the investments. Such a reallocation may increase the total

\footnotetext{
${ }^{7}$ Early Mark II work is summarized in Hart (1995), while Segal and Whinston (2012) also describe more recent
} 
surplus in the relation. However, it only about at the cost of reducing one of the parties' investment incentives (excepting the situation in which the parties' marginal costs of investment are equal). This trade-off determines the efficient allocation of ownership, and hence the efficient boundaries of the firm. Hence, the central issue becomes, Who should own the (non-human) asset for (second-best) efficiency to obtain? Note that this tacitly assumes that it is possible to unambiguously identify the owner of an asset. Specifically, Mark II property rights economics does not address (alienable) assets that are in the public domain in the sense that other individuals may spend resources on capturing them without compensating anyone (as in theft, homesteading, etc.) (Barzel, 1997). All alienable assets are fully in the private domain in the sense that ownership titles are perfectly defined and perfectly enforced. In contrast, Mark I property rights economists stressed that all property is potentially and to some extent in the public domain as the definition and enforcement of rights to assets are never perfect (Umbeck, 1981; Barzel, 1997). For this reason, ambiguity concerning who holds effective ownership can easily arise (Foss \& Foss, 2001). In fact, Demsetz (1998: 450) declares that the "generally more correct approach is to avoid speaking of asset ownership unless all rights to the asset are owned by one party," which in fact usually will not be the case; hence, ownership is illdefined in most real-world situations.

\section{Cutting the Gordian Knot?}

The inherent vagueness of the notion of ownership in Mark I property rights economics (which these scholars did not necessarily see as a problem) may seem to be at variance with the rather concrete meaning that ownership has in the law. In fact, Hart (1995: 30n) approvingly quotes Oliver Wendell Holmes understanding of ownership in support of his own view: "But what are the rights of ownership? They are substantially the same as those incident to possession. Within the limits prescribed by policy, the owner is allowed to exercise his natural powers over the subject-matter uninterfered with, and is more or less protected in excluding other people from such interference. 
The owner is allowed to exclude all, and is accountable to no one." (For a broader and more contemporary view, see Honorè, 1961).

Specifically, notions of property rights and ownership are introduced in the Mark II stream in the following way: A fundamental distinction obtains between specific rights of control that can be allocated by contract and residual rights of control that are allocated by ownership. Ownership is defined as the legally enforced possession of an asset. Thus, economic and legal conceptions of ownership are brought together (whereas Mark II property rights theorists increasingly dissociated economic and legal views). Specific rights of control are delineated and directly allocated through contract, while residual rights of control are obtained through the legal ownership of assets and imply the "right to decide usages of the asset in uncontracted-for contingencies" (Hart 1996: 371), as well as the right to "decide when or even whether to sell the asset" (Hart, 1995: 65). The economic importance of ownership stems from the owner's ability to exercise residual rights of control over the assets. In particular, an owner can issue threats of taking assets out of a relation.

The Mark II notion that ownership is what allocates residual rights of control would seem to be a conceptual sword cutting through the Gordian knot of the meaning of ownership, one that furthermore is firmly grounded in legal notions of ownership. However, the sword works by means of strong simplifications (Demsetz, 1998; Foss \& Foss, 2001), specifically the two closely related implicit assumptions that ownership is 1) well-defined and 2) perfectly enforced/non-contestable.

Ownership is well-defined. In his review of Hart (1995), Demsetz (1998: 449; emphasis in original) correctly points out that "Hart writes as though he thinks that asset ownership is an unambiguous concept." This is contrast to Mark I property rights economics, as indicated. Thus, Barzel (1997) argues that for the purposes of economic analysis, it is more fruitful to focus on the ownership of attributes of assets (i.e., as in Coase [1960] their multiple uses) rather than of assets. The reason is that most assets have so many attributes (many may be non-specified or as yet unknown) that the notion of ownership of assets is vague. Similarly, Demsetz' argue that "full private 
ownership" over assets is vague, and “... must always remain so, for there is an infinity of potential rights of actions that can be owned ... It is impossible to describe the complete set of rights that are potentially ownable" (Demsetz, 1988: 19).

It is clear that assuming that ownership is unambiguous because of perfect definition and enforceability of the relevant rights is convenient: It allows the equally unambiguous identification of the owner of any given (owned) asset. The issue of why it matters who owns the asset is, as stated, the central one in Mark II property rights economics.

The logic by which ownership comes to be seen as being an unambiguous construct is not entirely transparent. The other main rival in the literature is the notion of ownership as the possession of residual income rights, typically associated with the corporate finance literature (e.g.,La Porta, Lopez-De-Silanes \& Shleifer, 1999). Hart (1995: 63-66) suggests that the residual income notion is “... not a very robust or interesting theoretical concept" (1995: 64). Residual income rights are not useful as a notion of ownership, since they can easily be divided which residual control rights cannot “in the same way" (1995: 64n). Perhaps Hart means that allocate residual rights of control cannot be allocated ex ante between parties (Foss \& Foss, 2001). In contrast, residual rights to income can in principle be allocated ex ante in any way between the parties. While it is true that a given residual control right to a specific set of uses of an asset can be difficult to share between parties (Demsetz, 1998), this does not mean that residual control rights to assets are necessarily non-shareable between individuals. One can imagine arrangements where an individual effectively controls an asset (e.g., a taxi) on specific weekdays whereas another individual controls it on other weekdays. Hart admits that residual rights of control are in fact divisible in such a way (e.g., he talks about "forms of intermediate ownership" that cover this; p.61). Of course, while control rights may be divisible someone has to be the "ultimate" owner in the sense that only she can veto the use of an asset. Or, so it would seem. Consider a cooperative or a partnership. In these contractual arrangements, control is exercised by means of majority rule. In effect, decisions on what shall be done with assets in 
situations that are not covered by contract are decided by any majority that may happen to form.

Obviously, such majorities can change over time in terms of their composition. But this means that it is not possible to unambiguously link residual rights of control to any single identifiable individual, and it is means that the whole strategy of assuming that it is possible to unambiguously identify the owner of an asset is called into question. ${ }^{8}$

Asymmetric treatment of enforcement. A key insight that emerged in the evolution of Mark I property rights economics is that it is reasonable to draw a distinction between legal and economic rights (Alchian, 1965; Barzel, 1997). Legal rights may not translate into economic rights, because the relevant rights can only be enforced at high cost. Or, economic rights may not be matched by legal rights, because the costs of capturing rights are small but the costs of securing legal title to those rights are high. In the presence of such transaction costs, the distinction between legal and economic rights becomes meaningful with respect to potentially any asset, whether human capital assets or non-human capital assets (Barzel, 1997). However, this point does not seem to be reflected in Mark II property rights economics. Thus, ownership to, and contracts over, physical assets are supposed to be fully and costlessly enforced by the legal system, whereas contracts involving investments in human capital are assumed to be completely unenforceable because the relevant investments are assumed to be non-verifiable.

\section{Does It Matter?}

Coase (1974) argued that economists had too often been prone to offer verdicts on what are optimal ownership or financing patterns based on highly stylized models that are insufficiently grounded in empirical reality, taking the treatment of the lighthouse as the quintessential public good as an example. Thus, many economists had routinely taken lighthouse services as perfect examples

\footnotetext{
${ }^{8}$ A related problem concerns whether residual rights of control are only indirectly tradable through the exchange of ownership titles (Hart, 1995). Long-term leasing arrangements may effectively be identical to holding ownership, particularly if the leasing arrangement lasts through the economic lifetime of the asset (Wiggins, 1991: 610n) or if the arrangement comes with a first-buy clause (Foss \& Foss, 2001).
} 
of fully non-excludable and non-rivalrous goods. Looking into the relevant historical records, Coase documented how in the past lighthouse services had been in private supply, for example, by linking the financing of lighthouse to harbor fees. Thus, an element of excludability was added by the specific institutional arrangements that were adopted. In contrast, to simply define lighthouse services as pure public goods narrows the range of institutional alternatives for ownership and financing considerably.

In a sense, the treatment of asset ownership in Mark II property rights economics is a new lighthouse in economics. Thus, economists working within this stream have adopted a highly stylized notion of ownership that while it seems to conform to legal notions of ownership involves the problematic assumptions that ownership is indivisible, perfectly defined, and fully enforceable. In actuality, it is neither of these. As in the case of the traditional assumptions in the analysis of the lighthouse, this means that the analysis neglects real institutions, legal and otherwise, and that potentially errorneous explanations are put forward or that there are phenomena that the theory simply cannot address.

For example, Foss and Foss (2001) argue that Mark II property rights economics cannot discriminate between quasi-vertical integration (i.e., when a firm owns some of the specific assets deployed by its supplier) and full vertical integration, because the pattern of asset ownership may be the same under the two arrangements and therefore bargaining outcomes and incentives will be identical. ${ }^{9}$ However, legally these arrangements are completely different. This difficulty suggests a related difficult. In Mark II property rights economics, the source of authority in an employment relation is ultimately asset ownership. Such ownership confers bargaining power over the employee, because the employer can deprive the employee of the assets that make him (more) productive. However, it is not clear what is the difference between an employment relation thus conceived and

\footnotetext{
${ }^{9}$ For similar reasons, Holmström (1999: 100) says that "property rights theory, as articulated in Hart and Moore (1990) and other representative pieces, says very little about the firm."
} 
quasi-vertical integration (cf. also Hodgson, 2004). Again, however, the two institutions are legally entirely different.

The understanding of ownership also has potentially far-reaching consequences for corporate governance. Thus, drawing on relevant legal literature Chassagnon and Hollandts (2013) argue the issue of who owns the firm remains a vexing one. In fact, they conclude that legal scholarship lends support to the notion that no one in particular owns the corporation. Moreover, no one "... owns the firm because beyond the formal aspects of it that are recognized by law, the firm is a social organization that is institutionalized separately from the law" (Chassagnon \& Hollandts, 2013: 10). This does not mean that an economic analysis of the corporation is ruled out; on the contrary, the authors recommend placing "power" centrally in the analysis of firm boundaries and internal organization. Their notion of power is close to the notion of effective control, highlighted by Mark I property rights theorists as the hallmark of property rights (Barzel, 1997).

\section{CONCLUSION}

Few economists today define themselves as working in the Mark I property rights economics tradition. The publication of Grossman and Hart (1986) fundamentally changed discourse on property rights in economics. Arguably, because it had certain aesthetic and explanatory advantages relative to transaction cost economics (notably a unified approach to the costs of alternative governance structures) and because of its formal approach, Mark II property rights swept aside the older, mainly verbal approach, at least in terms of publications in the top economics journals.

Stigler (1983) argued that on efficient research markets, the true theoretical value of older contributions to economics will be internalized in contemporary contributions in more rigorous and pure form. Thus, with such markets, economic science grows with perfect recall, as it were. However, the economics profession is forgetful. A simple reason why ideas may be forgotten when the discoverer of those ideas dies, becomes interested in other subjects, etc. in other words, when the relevant ideas are no longer promoted (Anderson \& Tollison ,1986). Moreover, even in spite of promotion efforts by the 
inventor of ideas, the profession may remain ignorant of the relevant, important ideas if insufficient alertness (Kirzner, 1973) is exercised by its members. The spread of ideas needs promoters and discoverers; both of these may be lacking to some extent. Such informational inefficiencies provide some economics content to the Kuhnian idea of "loss of content" (Kuhn, 1970).

The history of economics witnesses many cases new theorizing involved introducing drastic simplifications and bypassing much of the subtlety of earlier research traditions. For example, the case has been made that the Keynesian revolution involved suppressing earlier, sophisticated thinking on asymmetric information and the role of relative prices in directing resource uses (e.g., from different perspectives, Lucas, 1977; Leijonhufvud, 1981). Many heterodox traditions in economics routinely make this case on behalf of their own revitalized tradition. In this study, we have made a case that the change from Mark I to Mark II property rights economics is another instance of a Kuhnian loss of content. Seemingly, Mark II property rights economics was able to resolve a number of unresolved problems in the older approach, such as the central issue of what it means to own an asset. The notion of residual rights of control seems to offer a clean answer to this. However, it is an answer that comes at the expense of making strong assumptions concerning the enforceability of titles to ownership and the divisibility of residual rights of control. When such assumptions are relaxed, ownership becomes a much more blurry concept. Although one can still meaningfully talk about who owns specific rights to use or income, it may often not be unambiguous who owns an asset, or indeed the corporation. However, this direct attention to the many ways through which individuals in actuality regulate the uses of assets and how individuals protection as well as capture of rights are enabled and constrained by real institutions, including legal and political institutions (Sened, 1997). Examining the multi-facetted nature and many different manifestations of ownership, and how these can be analyzed as the outcomes of constrained maximization within a institutional and political matrix, was a central explanatory task of Mark I property rights economics. In essence, this program was laid down in Coase (1960). Compared to this rich and ambitious 
program, the change from Mark I to Mark II property rights economics has resulted in a considerably more narrow analytical scope and more strongly simplified assumptions, in short there has arguably been a Kuhnian loss of content.

\section{REFERENCES}

ALCHIAN, A. A. (1958) Private Property and the Relative Cost of Tenure. In: BRADLEY, P. D. (ed). The Public Stake in Union Power. Charlottesville, Virginia: University of Virginia Press.

ALCHIAN, A. A. (1965) Some Economics of Property Rights. In: ALCHIAN, A. A. (1977) Economics Analysis of Property Rights. Indianapolis: Liberty Press.

ALCHIAN, A. A. \& ALLEN, W.R. (1969) Exchange and Production: Theory in Use. Belmont: Wadsworth.

ALCHIAN, A. A. \& DEMSETZ, H. (1972) Production, Information Costs, and Economic Organization. American Economic Review. 62. p. 772-795.

ALCHIAN, A. A. \& DEMSETZ, H. (1973) The Property Rights Paradigm. Journal of Economic History. 33. p. 16-27.

ALESSI, L. (1983) Property Rights, Transaction Costs, and X-Efficiency: An Essay in Economic Theory. American Economic Review. 73. p. 64-81.

ALESSI, L. (1990) Development of the Property Rights Approach. Journal of Institutional and Theoretical Economics. 146. p. 6-11.

ALLEN, D.W. (1991) What Are Transaction Costs? Research in Law and Economics. 14. p. 1-18. ALLEN, D.W. \& LUECK, D. (1995) Risk Preferences and the Economics of Contracts. American Economic Review. 85. p. 447-45.

ALLEN, D. \& LUECK, D. (1998) The Nature of the Farm. Journal of Law and Economics. 41. p. 343-386.

ANDERSON, G. \& TOLLISON, R.D. (1986). Dead Men Tell No Tales. History of Economics Society Bulletin. 8. p. 59-68.

ANDERSON, T.L. \& HILL, P.J. (1990) The Race for Property Rights. Journal of Law and Economics 33. p. 177-197.

BARZEL, Y. (1982) Measurement Costs and the Organization of Markets. Journal of Law and Economics 25. p. 27-48. 
BARZEL, Y. (1994) The Capture of Wealth by Monopolists and the Protection of Property Rights. International Review of Law and Economics. 14. p. 393-409.

BARZEL, Y. (1997) Economic Analysis of Property Rights. $2^{\text {nd }}$ edition. Cambridge: Cambridge University Press.

BUSH, W. \& MAYER, L. (1974) Some Implications of Anarchy for the Distribution of Property. Journal of Economic Theory. 8. p. 401-412.

CALABRESI, G. \& MELAMED, A.D. (1982) Property Rules, Liability Rules, and Inalienability: One View of the Cathedral. Harvard Law Review. 85. P. 1089-1128.

CHASSAGNON, V. \& HOLLANDTS, X. (2013). Who are the owners of the firm: shareholders, employees or no one? Journal of Institutional Economics (forthcoming).

CHEUNG, S.N.S. (1969) Transaction Costs, Risk Aversion, and the Choice of Contractual Arrangements. Journal of Law and Economics. 12. p. 23-42.

CHEUNG, S.N.S. (1970) The Structure of a Contract and the Theory of a Non-Exclusive Resource. Journal of Law and Economics. 13. p. 49-70.

CLAY, K. \& WRIGHT, G. (2005) Order without Law? Property Rights during the California Gold Rush. Explorations in Economic History. 42. p. 155-183.

COASE, R. H. (1937) The Nature of the Firm, in idem: (1988) The Firm, the Market and the Law. Chicago: University of Chicago Press.

COASE, R. H. (1959) The Federal Communications Commission. Journal of Law and Economics. 2. p. 1-40.

COASE, R. H. (1960) The Problem of Social Cost, in idem, (1988). The Firm, the Market and the Law. Chicago: University of Chicago Press.

COASE, R. H. (1974) The lighthouse in economics. Journal of Law and Economics. 17. p. 357-376.

COASE, R. H. (1988a) The Firm, the Market and the Law. Chicago: University of Chicago Press.

COASE, R. H. (1988b) Notes on the Problem of Social Cost, in idem: (1988) The Firm, the Market and the Law. Chicago: University of Chicago Press.

COMMONS, J.R. (1924) Legal Foundations of Capitalism. New York: MacMillan.

DEMSETZ, H. (1964) The Exchange and Enforcement of Property Rights. In: DEMSETZ, H. (1988) Ownership, Control, and the Firm. Oxford: Basil Blackwell, 1988.

DEMSETZ, H. (1964) The Exchange and Enforcement of Property Rights. Journal of Law and Economics. 7. p. 11-26.

DEMSETZ, H. (1967) Toward a Theory of Property Rights. In: DEMSETZ, H. (1988) Ownership, Control, and the Firm. Oxford: Basil Blackwell. 
DEMSETZ, H. (1982) Barriers to Entry. American Economic Review. 72. p. 47-57.

DEMSETZ, H. (1988) A Framework for the Study of Ownership. In: DEMSETZ, H. (1988)

Ownership, Control, and the Firm. Oxford: Basil Blackwell.

DEMSETZ, H. (1996) The Core Disagreement Between Pigou, the Profession, and Coase in the Analyses of the Externality Question. European Journal of Political Economy. 12. p. 565-580. DEMSETZ, H. (1998) Review: Oliver Hart, Firms, Contracts, and Financial Structure. Journal of Political Economy. 106. p. 446-452.

EGGERTSON, T. (1990) Economic Behavior and Institutions. Cambridge: Cambridge University Press.

FAMA, E. \& JENSEN, M.C. (1983) Separation of Ownership and Control. Journal of Law and Economics. 26. p. 301-326.

FOSS, K. \& FOSS, N.J. (2001) Assets, Attributes, and Ownership. International Journal of the Economics of Business. 8. p. 19-37.

FURUBOTN, E. \& PEJOVICH, S. (1972) Property Rights and Economic Theory: A Survey of Recent Literature. Journal of Economic Literature. 10. p. 1137-1162.

FURUBOTN, E.G. (1991) General equilibrium models, transaction costs, and the concept of efficient allocation in a capitalist economy. Journal of Institutional and Theoretical Economics. 147. p. 662-686.

GROSSMAN, S. \& HART, O. (1986) The Costs and Benefits of Ownership: A Theory of Lateral and Vertical Integration. Journal of Political Economy. 94. p. 691-719.

HART, O. (1995) Firms, Contracts and Financial Structure. Oxford: Clarendon Press.

HART, O. (1996) An Economist's View of Authority. Rationality and Society. 8. p. 371-386.

HART, O. \& MOORE, J. (1990) Property Rights and the Nature of the Firm. Journal of Political Economy. 98. p. 1119-1158.

HART, O. \& MOORE, J. (1994) The Governance of Exchanges: Members' Cooperatives Versus Outside Ownership. Mimeo: Harvard University.

HOLMSTRÖM, B. (1999). The Firm as a Subeconomy. Journal of Law, Economics, and Organization. 15. p. 74-102.

HONORÈ, A.M. (1961). Ownership. In Guest, A.G. (ed.) Oxford Essays in Jurisprudence. Oxford: Oxford University Press.

JENSEN, M.C. \& MECKLING, W. (1976) Theory of the Firm: Managerial Behavior, Agency Costs and Ownership Structure. Journal of Finance. 3. p. 305-360.

KIRZNER, I.M. (1973) Competition and Entrepreneurship. Chicago: University of Chicago Press. 
KLEIN, B., CRAWFORD, R.G. \& ALCHIAN, A.A. (1978) Vertical Integration, Appropriable Rents, and the Competitive Contracting Process. Journal of Law and Economics. 21. p. 297 326.

KNIGHT, F.H. (1924) Some Fallacies in the Interpretation of Social Cost. Quarterly Journal of Economics. 38 (4). p. 582-606.

KREPS, D. M. (1996) Markets and Hierarchies and (Mathematical) Economic Theory. Industrial and Corporate Change. 5. p. 561-596.

KUHN, T. S. (1996) The Structure of Scientific Revolutions. 3rd edition. Chicago, IL: University of Chicago Press.

LAPORTA, R., LOPEZ-DE-SILANES,' F., \& SHLEIFER, A. (1999). Corporate Ownership Around the World. The Journal of Finance. 54. p. 471-517.

LEIJONHUFVUD, A. (1981) Information and coordination: Essays in Macroeconomic Theory. Oxford: Oxford University Press.

LIBECAP, G. P. (1989) Contracting for Property Rights, Cambridge. Cambridge University Press. LUCAS, R.E. (1977) Understanding Business Cycles. In idem. 1982. Studies in Business Cycle Theory. Cambridge, MA: MIT Press.

LUECK, D. (1995) The Rule of First Possession and the Design of the Law. Journal of Law and Economics. 38. p. 393-436.

MISES, L.v. (1936) Socialism. Indianapolis: Liberty Press.

NORTH, D.C. (1990) Institutions, Institutional Change, and Economic Performance. Cambridge: Cambridge University Press.

SEGAL, I. \& WHINSTON, M.D. (2012) Property Rights. In GIBBONS, R. \& ROBERTS, J., eds. (2012). The Handbook of Organizational Economics. Princeton: Princeton University Press. SENED, I. (1997). The Political Institution of Private Property. Cambridge: Cambridge University Press.

STIGLER, G.J. (1983) Nobel Lecture: The Process and Progress of Economics. Journal of Political Economy. 91. p.529-543.

UMBECK, J. (1981) Might Makes Rights: A Theory of the Formation and Initial Distribution of Property Rights. Economic Inquiry. 19. p. 38-59.

WIGGINS, S. N. (1991) The Economics of the Firm and Contracts: A Selective Survey. Journal of Institutional and Theoretical Economics. 147. p. 603-661.

WILLIAMSON, O. E. (1971) The Vertical Integration of Production: Market Failure Considerations. American Economic Review. 61. p. 112-123. 
WILLIAMSON, O.E. (1985) The Economic Institutions of Capitalism. New York: The Free Press. WILLIAMSON, O.E. (1996) The Mechanisms of Governance. Oxford: Oxford University Press. WILLIAMSON, O.E. (2000) The New Institutional Economics: Taking Stock, Looking Ahead. Journal of Economic Literature. 38. p. 595-613. 


\section{SMG - Working Papers \\ www.cbs.dk/smg \\ 2003}

2003-1: Nicolai J. Foss, Kenneth Husted, Snejina Michailova, and Torben Pedersen: Governing Knowledge Processes: Theoretical Foundations and Research Opportunities.

2003-2: Yves Doz, Nicolai J. Foss, Stefanie Lenway, Marjorie Lyles, Silvia Massini, Thomas P. Murtha and Torben Pedersen: Future Frontiers in International Management Research: Innovation, Knowledge Creation, and Change in Multinational Companies.

2003-3: Snejina Michailova and Kate Hutchings: The Impact of In-Groups and OutGroups on Knowledge Sharing in Russia and China CKG Working Paper.

2003-4: Nicolai J. Foss and Torben Pedersen: The MNC as a Knowledge Structure: The Roles of Knowledge Sources and Organizational Instruments in MNC Knowledge Management CKG Working Paper.

2003-5: Kirsten Foss, Nicolai J. Foss and Xosé H. Vázquez-Vicente: “Tying the Manager's Hands": How Firms Can Make Credible Commitments That Make Opportunistic Managerial Intervention Less Likely CKG Working Paper.

2003-6: Marjorie Lyles, Torben Pedersen and Bent Petersen: Knowledge Gaps: The Case of Knowledge about Foreign Entry.

2003-7: Kirsten Foss and Nicolai J. Foss: The Limits to Designed Orders: Authority under "Distributed Knowledge" CKG Working Paper.

2003-8: Jens Gammelgaard and Torben Pedersen: Internal versus External Knowledge Sourcing of Subsidiaries - An Organizational Trade-Off.

2003-9: Kate Hutchings and Snejina Michailova: Facilitating Knowledge Sharing in Russian and Chinese Subsidiaries: The Importance of Groups and Personal Networks Accepted for publication in Journal of Knowledge Management.

2003-10: Volker Mahnke, Torben Pedersen and Markus Verzin: The Impact of Knowledge Management on MNC Subsidiary Performance: the Role of Absorptive Capacity CKG Working Paper.

2003-11: Tomas Hellström and Kenneth Husted: Mapping Knowledge and Intellectual Capital in Academic Environments: A Focus Group Study Accepted for publication in Journal of Intellectual Capital CKG Working Paper.

2003-12: Nicolai J Foss: Cognition and Motivation in the Theory of the Firm: Interaction or "Never the Twain Shall Meet"? Accepted for publication in Journal des Economistes et des Etudes Humaines CKG Working Paper.

2003-13: Dana Minbaeva and Snejina Michailova: Knowledge Transfer and Expatriation Practices in MNCs: The Role of Disseminative Capacity.

2003-14: Christian Vintergaard and Kenneth Husted: Enhancing Selective Capacity Through Venture Bases. 


\section{4}

2004-1: Nicolai J. Foss: Knowledge and Organization in the Theory of the Multinational Corporation: Some Foundational Issues

2004-2: Dana B. Minbaeva: HRM Practices and MNC Knowledge Transfer

2004-3: Bo Bernhard Nielsen and Snejina Michailova: Toward a Phase-Model of Global Knowledge Management Systems in Multinational Corporations

2004-4: Kirsten Foss \& Nicolai J Foss: The Next Step in the Evolution of the RBV: Integration with Transaction Cost Economics

2004-5: Teppo Felin \& Nicolai J. Foss: Methodological Individualism and the Organizational Capabilities Approach

2004-6: Jens Gammelgaard, Kenneth Husted, Snejina Michailova: Knowledge-sharing Behavior and Post-acquisition Integration Failure

2004-7: Jens Gammelgaard: Multinational Exploration of Acquired R\&D Activities

2004-8: Christoph Dörrenbächer \& Jens Gammelgaard: Subsidiary Upgrading? Strategic Inertia in the Development of German-owned Subsidiaries in Hungary

2004-9: Kirsten Foss \& Nicolai J. Foss: Resources and Transaction Costs: How the Economics of Property Rights Furthers the Resource-based View

2004-10: Jens Gammelgaard \& Thomas Ritter: The Knowledge Retrieval Matrix: Codification and Personification as Separate Strategies

2004-11: Nicolai J. Foss \& Peter G. Klein: Entrepreneurship and the Economic Theory of the Firm: Any Gains from Trade?

2004-12: Akshey Gupta \& Snejina Michailova: Knowledge Sharing in Knowledge-Intensive Firms: Opportunities and Limitations of Knowledge Codification

2004-13: Snejina Michailova \& Kate Hutchings: Knowledge Sharing and National Culture: A Comparison Between China and Russia

\section{5}

2005-1: Keld Laursen \& Ammon Salter: My Precious - The Role of Appropriability Strategies in Shaping Innovative Performance

2005-2: Nicolai J. Foss \& Peter G. Klein: The Theory of the Firm and Its Critics: A Stocktaking and Assessment

2005-3: Lars Bo Jeppesen \& Lars Frederiksen: Why Firm-Established User Communities Work for Innovation: The Personal Attributes of Innovative Users in the Case of Computer-Controlled Music

2005-4: Dana B. Minbaeva: Negative Impact of HRM Complementarity on Knowledge Transfer in MNCs

2005-5: Kirsten Foss, Nicolai J. Foss, Peter G. Klein \& Sandra K. Klein: Austrian Capital 
Theory and the Link Between Entrepreneurship and the Theory of the Firm

2005-1: Nicolai J. Foss: The Knowledge Governance Approach

2005-2: Torben J. Andersen: Capital Structure, Environmental Dynamism, Innovation Strategy, and Strategic Risk Management

2005-3: Torben J. Andersen: A Strategic Risk Management Framework for Multinational Enterprise

2005-4: Peter Holdt Christensen: Facilitating Knowledge Sharing: A Conceptual Framework

2005-5 Kirsten Foss \& Nicolai J. Foss: Hands Off! How Organizational Design Can Make Delegation Credible

2005-6 Marjorie A. Lyles, Torben Pedersen \& Bent Petersen: Closing the Knowledge Gap in Foreign Markets - A Learning Perspective

2005-7 Christian Geisler Asmussen, Torben Pedersen \& Bent Petersen: How do we Capture "Global Specialization" when Measuring Firms' Degree of internationalization?

2005-8 Kirsten Foss \& Nicolai J. Foss: Simon on Problem-Solving: Implications for New Organizational Forms

2005-9 Birgitte Grøgaard, Carmine Gioia \& Gabriel R.G. Benito: An Empirical Investigation of the Role of Industry Factors in the Internationalization Patterns of Firms

2005-10 Torben J. Andersen: The Performance and Risk Management Implications of Multinationality: An Industry Perspective

2005-11 Nicolai J. Foss: The Scientific Progress in Strategic Management: The case of the Resource-based view

2005-12 Koen H. Heimeriks: Alliance Capability as a Mediator Between Experience and Alliance Performance: An Empirical Investigation Into the Alliance Capability Development Process

2005-13 Koen H. Heimeriks, Geert Duysters \& Wim Vanhaverbeke: Developing Alliance Capabilities: An Empirical Study

2005-14 JC Spender: Management, Rational or Creative? A Knowledge-Based Discussion

\section{6}

2006-1: Nicolai J. Foss \& Peter G. Klein: The Emergence of the Modern Theory of the Firm

2006-2: Teppo Felin \& Nicolai J. Foss: Individuals and Organizations: Thoughts on a Micro-Foundations Project for Strategic Management and Organizational Analysis

2006-3: Volker Mahnke, Torben Pedersen \& Markus Venzin: Does Knowledge Sharing 
Pay? An MNC Subsidiary Perspective on Knowledge Outflows

2006-4: Torben Pedersen: Determining Factors of Subsidiary Development

2006-5 Ibuki Ishikawa: The Source of Competitive Advantage and Entrepreneurial Judgment in the RBV: Insights from the Austrian School Perspective

2006-6 Nicolai J. Foss \& Ibuki Ishikawa: Towards a Dynamic Resource-Based View: Insights from Austrian Capital and Entrepreneurship Theory

2006-7 Kirsten Foss \& Nicolai J. Foss: Entrepreneurship, Transaction Costs, and Resource Attributes

2006-8 Kirsten Foss, Nicolai J. Foss \& Peter G. Klein: Original and Derived Judgement: An Entrepreneurial Theory of Economic Organization

2006-9 Mia Reinholt: No More Polarization, Please! Towards a More Nuanced Perspective on Motivation in Organizations

2006-10 Angelika Lindstrand, Sara Melen \& Emilia Rovira: Turning social capital into business? A study of Swedish biotech firms' international expansion

2006-11 Christian Geisler Asmussen, Torben Pedersen \& Charles Dhanaraj: Evolution of Subsidiary Competences: Extending the Diamond Network Model

2006-12 John Holt, William R. Purcell, Sidney J. Gray \& Torben Pedersen: Decision Factors Influencing MNEs Regional Headquarters Location Selection Strategies

2006-13 Peter Maskell, Torben Pedersen, Bent Petersen \& Jens Dick-Nielsen: Learning Paths to Offshore Outsourcing - From Cost Reduction to Knowledge Seeking

2006-14 Christian Geisler Asmussen: Local, Regional or Global? Quantifying MNC Geographic Scope

2006-15 Christian Bjørnskov \& Nicolai J. Foss: Economic Freedom and Entrepreneurial Activity: Some Cross-Country Evidence

2006-16 Nicolai J. Foss \& Giampaolo Garzarelli: Institutions as Knowledge Capital: Ludwig M. Lachmann's Interpretative Institutionalism

2006-17 Koen H. Heimriks \& Jeffrey J. Reuer: How to Build Alliance Capabilities

2006-18 Nicolai J. Foss, Peter G. Klein, Yasemin Y. Kor \& Joseph T. Mahoney: Entrepreneurship, Subjectivism, and the Resource - Based View: Towards a New Synthesis

2006-19 Steven Globerman \& Bo B. Nielsen: Equity Versus Non-Equity International Strategic Alliances: The Role of Host Country Governance

\section{7}

2007-1 Peter Abell, Teppo Felin \& Nicolai J. Foss: Building Micro-Foundations for the Routines, Capabilities, and Performance Links 
2007-2 Michael W. Hansen, Torben Pedersen \& Bent Petersen: MNC Strategies and Linkage Effects in Developing Countries

2007-3 Niron Hashai, Christian G. Asmussen, Gabriel R.G. Benito \& Bent Petersen: Predicting the Diversity of Foreign Entry Modes

2007-4 Peter D. Ørberg Jensen \& Torben Pedersen: Whether and What to Offshore?

2007-5 Ram Mudambi \& Torben Pedersen: Agency Theory and Resource Dependency Theory: Complementary Explanations for Subsidiary Power in Multinational Corporations

2007-6 Nicolai J. Foss: Strategic Belief Management

2007-7 Nicolai J. Foss: Theory of Science Perspectives on Strategic Management Research: Debates and a Novel View

2007-8 Dana B. Minbaeva: HRM Practices and Knowledge Transfer in MNCs

2007-9 Nicolai J. Foss: Knowledge Governance in a Dynamic Global Context: The Center for Strategic Management and Globalization at the Copenhagen Business School

2007-10 Paola Gritti \& Nicolai J. Foss: Customer Satisfaction and Competencies: An Econometric Study of an Italian Bank

2007-11 Nicolai J. Foss \& Peter G. Klein: Organizational Governance

2007-12 Torben Juul Andersen \& Bo Bernhard Nielsen: The Effective Ambidextrous Organization: A Model of Integrative Strategy Making Processes.

\section{8}

2008-1 Kirsten Foss \& Nicolai J. Foss: Managerial Authority When Knowledge is Distributed: A Knowledge Governance Perspective

2008-2 Nicolai J. Foss: Human Capital and Transaction Cost Economics.

2008-3 Nicolai J. Foss \& Peter G. Klein: Entrepreneurship and Heterogeneous Capital.

2008-4 Nicolai J. Foss \& Peter G. Klein: The Need for an Entrepreneurial Theory of the Firm.

2008-5 Nicolai J. Foss \& Peter G. Klein: Entrepreneurship: From Opportunity Discovery to Judgment.

2008-6 Mie Harder: How do Rewards and Management Styles Influence the Motivation to Share Knowledge?

2008-7 Bent Petersen, Lawrence S. Welch \& Gabriel R.G. Benito: Managing the Internalisation Process - A Theoretical Perspective.

2008-8 Torben Juul Andersen: Multinational Performance and Risk Management Effects: Capital Structure Contingencies. 
2008-9 Bo Bernard Nielsen: Strategic Fit and the Role of Contractual and Procedural Governance in Alliances: A Dynamic Perspective.

2008-10 Line Gry Knudsen \& Bo Bernhard Nielsen: Collaborative Capability in R\&D Alliances: Exploring the Link between Organizational and Individual level Factors.

2008-11 Torben Juul Andersen \& Mahesh P. Joshi: Strategic Orientations of Internationalizing Firms: A Comparative Analysis of Firms Operating in Technology Intensive and Common Goods Industries.

2008-12 Dana Minbaeva: HRM Practices Affecting Extrinsic and Intrinsic Motivation of Knowledge Receivers and their Effect on Intra-MNC Knowledge Transfer.

2008-13 Steen E. Navrbjerg \& Dana Minbaeva: HRM and IR in Multinational Corporations: Uneasy Bedfellows?

2008-14 Kirsten Foss \& Nicolai J. Foss: Hayekian Knowledge Problems in Organizational Theory.

2008-15 Torben Juul Andersen: Multinational Performance Relationships and Industry Context.

2008-16 Larissa Rabbiosi: The Impact of Subsidiary Autonomy on MNE Knowledge Transfer: Resolving the Debate.

2008-17 Line Gry Knudsen \& Bo Bernhard Nielsen: Organizational and Individual Level Antecedents of Procedural Governance in Knowledge Sharing Alliances.

2008-18 Kirsten Foss \& Nicolai J. Foss: Understanding Opportunity Discovery and Sustainable Advantage: The Role of Transaction Costs and Property Rights.

2008-19 Teppo Felin \& Nicolai J. Foss: Social Reality, The Boundaries of Self-fulfilling Prophecy, and Economics.

2008-20 Yves Dos, Nicolai J. Foss \& José Santos: A Knowledge System Approach to the Multinational Company: Conceptual Grounding and Implications for Research

2008-21 Sabina Nielsen \& Bo Bernhard Nielsen: Why do Firms Employ foreigners on Their Top Management Teams? A Multi-Level Exploration of Individual and Firm Level Antecedents

2008-22 Nicolai J. Foss: Review of Anders Christian Hansen's “Uden for hovedstrømmen - Alternative strømninger i økonomisk teori"

2008-23 Nicolai J. Foss: Knowledge, Economic Organization, and Property Rights

2008-24 Sjoerd Beugelsdijk, Torben Pedersen \& Bent Petersen: Is There a Trend Towards Global Value Chain Specialization? - An Examination of Cross Border Sales of US Foreign Affiliates 
2008-25 Vikas Kumar, Torben Pedersen \& Alessandro Zattoni: The performance of business group firms during institutional transition: A longtitudinal study of Indian firms

2008-26 Sabina Nielsen \& Bo B. Nielsen: The effects of TMT and Board Nationality Diversity and Compensation on Firm Performance

2008-27 Bo B. Nielsen \& Sabina Nielsen: International Diversification Strategy and Firm Performance: A Multi-Level Analysis of Firm and Home Country Effects

\section{9}

2009-1 Nicolai J. Foss: Alternative Research Strategies in the Knowledge Movement: From Macro Bias to Micro-Foundations and Multi-Level Explanation

2009-2 Nicolai J. Foss \& Peter G. Klein: Entrepreneurial Alertness and Opportunity Discovery: Origins, Attributes, Critique

2009-3 Nicolai J. Foss \& Dana B. Minbaeva: Governing Knowledge: The Strategic Human Resource Management Dimension

2009-4 Nils Stieglitz \& Nicolai J. Foss: Opportunities and New Business Models: Transaction Cost and Property Rights Perspectives on Entrepreneurships

2009-5 Torben Pedersen: Vestas Wind Systems A/S: Exploiting Global R\&D Synergies

2009-6 Rajshree Agarwal, Jay B. Barney, Nicolai J. Foss \& Peter G. Klein: Heterogeneous Resources and the Financial Crisis: Implications of Strategic Management Theory

2009-7 Jasper J. Hotho: A Measure of Comparative Institutional Distance

2009-8 Bo B. Nielsen \& Sabina Nielsen: The Impact of Top Management Team Nationality Diversity and International Experience on Foreign Entry Mode

2009-9 Teppo Felin \& Nicolai Juul Foss: Experience and Repetition as Antecedents of Organizational Routines and Capabilities: A Critique of Behaviorist and Empiricist Approaches

2009-10 Henk W. Volberda, Nicolai J. Foss \& Marjorie E. Lyles: Absorbing the Concept of Absorptive Capacity: How To Realize Its Potential in the Organization Field

2009-11 Jan Stentoft Arlbjørn, Brian Vejrum Wæhrens, John Johansen \& Torben Pedersen: Produktion i Danmark eller offshoring/outsourcing: Ledelsesmæssige udfordringer 


\section{0}

2010-1 Dana B. Minbaeva, Kristiina Mäkelä \& Larissa Rabbiosi: Explaining Intraorganizational Knowledge Transfer at the Individual Level

2010-2 Dana B.Minbaeva \& Torben Pedersen: Governing Individual Knowledge Sharing Behavior

2010-3 Nicolai J. Foss \& Peter G. Klein: Alertness, Judgment, and the Antecedents of Entrepreneurship

2010-4 Nicolai J.Foss \& Joseph T.Mahoney: Exploring Knowledge Governance

2010-5 Jasper J. Hotho, Florian Becker-Ritterspach \& Ayse Saka-Helmhout: Enriching Absorptive Capacity Through Social Interaction

2010-6 Nicolai J. Foss \& Bo B. Nielsen: Researching Collaborative Advantage: Some Conceptual and Multi-level Issues

2010-7 Nicolai J. Foss \& Nils Stieglitz: Modern Resource-Based Theory(ies)

2010-8 Christian Bjørnskov \& Nicolai J. Foss: Do Economic Freedom and Entrepreneurship Impact Total Factor Productivity?

2010-9 Gabriel R.G. Benito, Bent Petersen \& Lawrence S. Welch: Mode Combinations and International Operations: Theoretical Issues and an Empirical Investigation

\section{1}

2011-1 Peter D. Ørberg Jensen \& Bent Petersen: Human Asset Internalization and Global Sourcing of Services - A Strategic Management Analysis on Activity-level

2011-2 Mie Harder: Management Innovation Capabilities: A Typology and Propositions for Management Innovation Research

2011-3 Mie Harder: Internal Antecedents of Management Innovation: The effect of diagnostic capability and implementation capability 
2011-4 Mie Harder: Explaining Management Innovation Pervasiveness: The Role of Internal Antecedents

2011-5 Mie Harder: Internal Determinants of Product Innovation and Management Innovation: The Effect of Diagnostic Capability and Implementation Capability

2011-6 Nicolai J. Foss, Peter G. Klein \& Per L. Bylund: Entrepreneurship and the Economics of the Firm

2011-7 Nicolai J. Foss \& Jacob Lyngsie: The Emerging Strategic Entrepreneurship Field: Origins, Key Tenets and Research Gaps

2011-8 Nicolai J. Foss: Entrepreneurship in the Context of the Resource-based View of the Firm

2011-9 Bent Petersen, Gabriel R.G. Benito, Olesya Dovgan \& Lawrence Welch: Offshore outsourcing: A dynamic, operation mode perspective

2011-10 Bent Petersen, Gabriel R. G. Benito \& Lawrence Welch: Dynamics of Foreign Operation Modes and their Combinations: Insights for International Strategic Management

2011-11 Nicolai J. Foss: Teams, Team Motivation, and the Theory of the Firm

2011-12 Nicolai J. Foss: Knowledge Governance: Meaning, Nature, Origins, and Implications

2011-13 Nicolai J. Foss, Kirsten Foss \& Phillip C. Nell: MNC Organizational Form and Subsidiary Motivation Problems: Controlling Intervention Hazards in the Network MNC

2011-14 Kåre Moberg: Evaluating Content Dimensions in Entrepreneurship Education

\section{2}

2012-1 Nicolai J. Foss, Nicholas Argyres, Teppo Felin \& Todd Zenger: The Organizational Economics of Organizational Capability and Heterogeneity: A Research Agenda 
2012-2 Torben J. Andersen, Carina Antonia Hallin \& Sigbjørn Tveterås: A Prediction Contest: The Sensing of Frontline Employees Against Executive Expectations

2012-3 Peter G. Klein, Jay B. Barney \& Nicolai J. Foss: Strategic Entrepreneurship

2012-4 Kåre Moberg: The Impact of Entrepreneurship Education and Project-based Education on Students' Personal Development and Entrepreneurial Intentions at the Lower Levels of the Educational System: Too Much of Two Good Things?

2012-5 Keld Laursen \& Nicolai J. Foss: Human Resource Management Practices and Innovation

2012-6 Kåre Moberg: An Entrepreneurial Self-Efficacy Scale with a Neutral Wording

\section{3}

2013-1

Nicolai J. Foss, Diego Stea: The Principal's Theory of Mind: The Role of Mentalizing for Reward Design and Management in Principal-Agent Relations

2013-2 Dana Minbaeva, Chansoo Park \& Ilan Vertinsky: The Influence of Foreign Partners' Disseminative Capacities on Knowledge Transfers to International Joint Ventures

2013-3

Nicolai J. Foss \& Peter G. Klein: Hayek and Organizational Studies

2013-4 Kåre Moberg, Lene Vestergaard, Casper Jørgensen, Elisabeth Markussen \& Sose Hakverdyan: How to Assess the Development of Entrepreneurship Education at University Level - the Case of Denmark

2013-5 Nicolai J. Foss \& Siegwart Lindenberg: Micro-Foundations For Strategy: A Goal-Framing Perspective on the Drivers of Value Creation 
2013-6 Nicolai J. Foss, Jacob Lyngsie \& Shaker A. Zahra: The Role of External Knowledge Sources and Organizational Design in the Process of Opportunity Exploitation

2013-7 Stefan Linder \& Nicolai J. Foss: Agency Theory.

2013-8 Nicolai J. Foss, Peter G. Klein, Stefan Linder: Organizations and Markets

2013-9 Nicolai J. Foss: Towards an Organizational Economics of Heterogeneous Capabilities

2013- 10 Christian Geisler Asmussen \& Nicolai J. Foss: Competitive Advantage and the Existence of the MNC: Earlier Research and the Role of Frictions

\section{4}

2014-1 Nicolai J. Foss \& Kirsten Foss: COASIAN AND MODERN PROPERTY RIGHTS ECONOMICS: A CASE OF KUHNIAN LOST CONTENT 